Copyright (C) 2015 by Academic Publishing House Researcher

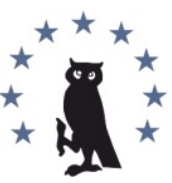

Published in the Russian Federation

European Researcher

Has been issued since 2010 .

ISSN 2219-8229

E-ISSN 2224-0136

Vol. 93, Is. 4, pp. 335-343, 2015

DOI: 10.13187/ er.2015.93.335

www.erjournal.ru

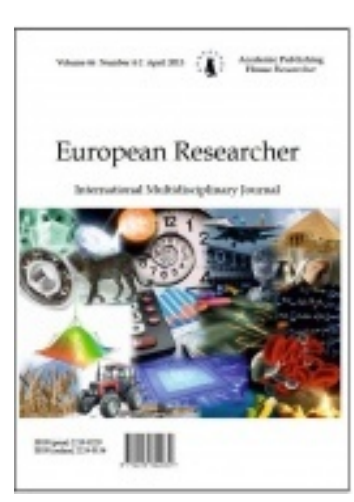

UDC 37

\title{
Analyzing the Role of Private Colleges in Developing the Effective Education System in Pakistan
}

15yed Zubair Haider*

${ }^{2}$ Azra Shaheen

1 Islamia University of Bahawalpur, Pakistan

$\mathrm{PhD}$ Candidate

E-mail: zubairiub@hotmail.com

${ }^{2}$ Islamia University of Bahawalpur, RYK Campus, Pakistan

Research Scholar

E-mail: sweetpalm40@yahoo.com

\begin{abstract}
Private Colleges are a vital source of quality education. They are producing intellectual and responsible students as the students are evaluated continuously. Therefore, they strive to perform better and to obtain good result. A sizeable number of citizens criticize private colleges for charging high fees and dues, but they never acknowledged the efforts in developing their children's educational competencies and learning abilities. The main inspiration of this study was to analyze the role of private colleges in developing the effective educational system in the district Rahim Yar Khan. A quantitative approach was used, with data being collected through questionnaire on five point Likert Scale. The questionnaire was administered upon the sample of 300 respondents (100 teachers and 200 students) from seven private colleges. The Statistical Package for Social Sciences (SPSS version 19) was employed to analyze the collected data. A number of descriptive statistics including Chi Square, mean, standard deviation and percentage were calculated.
\end{abstract}

Keywords: private colleges; Education system; competencies; learning abilities; Pakistan.

\section{Introduction}

Education plays an essential role in the development of our country's younger generation to lead a successful life in this world of dynamic and global competition. There are many aspects of education in the development of human personality. Education helps us to give professional knowledge and teaches us human skills. It helps to utilize our mind on creative thinking. It also helps in building our personality confidence and self-esteem. Education has helped in increasing people's awareness about the opportunities and levels for advancement. Education has become even more important because we live in a knowledge-based society driven by information technology. A well educated population can easily attain and make better use of potentials of upcoming progress and economic opportunities for advancement in the globalised environment.

In Pakistan most of educational institutions are supported by state or central government and these institutions perform as nonprofit organizations. While the private education may be define as

\footnotetext{
${ }^{*}$ (Corresponding Author)
} 
all the educational institutions that are not under the patronage of government and found, managed and finance by entrepreneur other than government (Niazi and Mace, 2006). In Pakistani education system, the participation of private sector and its development has many ups and downs. Since 1947 to 1971, it was usually managed, contributed and expanded through many Non Governmental Organizations (NGOs). The function of private sector education was completely eliminated after the process of nationalization (1972-1979) introduced by the government of that time. After concluding the nationalization policy in 1980, the same situation remain persist and the participation of private sector in the main stream education was negligible till 1998. After that, the National Education Policy (1998) emphasized that, the process of grant-in-aid should again continue to attract private sector and convince them to participate in educational activities.

The concept of private higher education in Pakistan, first come in the context of professional higher education. These professional education programmes usually based on long period of time. The important fact is that the owners of private educational institutions realized that there is sizeable number of students who can bear the expenses of private higher education. Now after professional educational programmes, the private education institutions are also entering in general education. Private higher education institutions are also very helpful to develop a pool of talented students that could be utilized by the institution in the form of giving its qualified students employment at the institution.

Dronkers and Avram (2010) pointed that even small in numbers, the private educational institutions are nonetheless similar to public schools. The main benefits of private educational institutions are that they are more independent and self-sustained. The dissatisfaction of students and their parents towards quality higher education in public sector leads their thinking to attend private colleges (Rose, 2009; Tooley \& Dixon, 2005). Privately owned educational institutions, therefore, enter as an appropriate choice for the students who are extremely interested to get the education in the field they desire at the time when they need it. It is obviously good to have such a focus and, in fact, any efforts of changes are inevitable to fail unless they concentrate on the characteristics and potentials of individual learner.

To structure the role of the private sector is not meant just to increase the number of private institutes rather in having quality ones, that would meet the needs and aspirations of a modern and prosperous Pakistan. The increased number of private educational institutions that could be seen today may not necessarily show an image a healthy development. On the other side, that may be the consequence of the sorry state of our public sector institutes. The government has its own fundamental role to play which involves monitoring and evaluating the activities of private sector educational institutions, encouraging those institutes which are playing a positive role in providing the quality education services at affordable price, and taking action against those who are a black spot and a danger to the field of education.

There is a mistaken belief that the outcomes of private colleges are sure to be better for every individual student; however it depends completely on the careful assessment and evaluation of an individual child. There are both merits and demerits of private colleges.

\section{Research Design}

Participants of Study

The research study was conducted to analyze the role of private colleges in developing the effective education system in Pakistan. In order to observe the relative effectiveness a quantitative inquiry was adopted for this study. As the study focus on current situation and keeping in view the nature of study, a descriptive research design was found appropriate for this study (Haider and Hussain, 2014) Gay and Airasian (2002) revealed that descriptive research used to describe and interpret what it is. Among different descriptive research designs, the survey research was considered to be the most suitable to extract reliable results. The study population includes all the boys and girls students and all the male and female teachers of private colleges situated in district Rahim Yar Khan. For the true representation, Simple random sampling technique was used for this study. It is always preferred due to enhanced generalizability with wider involvement of participants According to the objectives of this study; responses were collected from 100 teachers and 200 students of seven private colleges from three main cities (Rahim Yar Khan, Khan Pur and Sadiqabad) of district Rahim Yar Khan. These Private Colleges include Punjab College, NICAAS 
College and NICE College from Rahim Yar Khan, MTB College and IQRA Degree College from Sadiq Abad and NICAAS College and Superior College from Khan Pur.

Instruments and data collection

Development of the questionnaire is an important, careful and difficult task. Whole research depends upon the valid and reliable questionnaire. Thus, Development of the questionnaires was based on the recognized facets. Questionnaire was developed with great care and researcher continuously seeks out advice from the research experts. 20 items questionnaire was developed by researchers and used among college teachers and student. This questionnaire gathered responses on various aspects of role of private college on development of effective education system in Pakistan. A five-point Likert scale from (Strongly Agree $(\mathrm{SA}=5)$ to Strongly Disagree (SDA=1) was used.

Data Analysis Procedure

Data collected through questionnaires on five point Likert Scale were scored and analyzed using SPSS. The Percentage, mean score, standard deviation and chi-square were calculated. The researchers decided norm for statement rejection or acceptance on the basis of responses was 3.0. Average score above than 3.0 pointed the agreement while the value of mean score below than 3.0 indicate disagreement of respondent with the statement. Following formulas were used to calculate the mean score of each statement.

a) Positive Statement:

$\underline{\mathrm{SA}} * 5+\mathrm{A} * 4+\mathrm{U} * 3+\mathrm{D} * 2+\mathrm{SD} * 1$

Total No. of students

b) Negative Statement:

$\underline{\mathrm{SA}} * 1+\mathrm{A} * 2+\mathrm{U} * 3+\mathrm{D} * 4+\mathrm{SD} * 5$

Total No. of students

\section{Results}

This study sought information on analyzing the role of private colleges in the development of effective education system. The data obtained from teachers and students of private colleges and summarized in tables.

Table 1: Teacher's opinions about (Educational Development, Students Development, and Educational Interest)

\begin{tabular}{|c|c|c|c|c|c|c|c|c|}
\hline \multirow{2}{*}{ Category } & \multirow{2}{*}{ Statement } & \multicolumn{5}{|c|}{ Percentage (\%) } & \multirow{2}{*}{$\begin{array}{l}\text { Mean } \\
(\mathrm{X})\end{array}$} & \multirow{2}{*}{$\begin{array}{l}\text { S.D } \\
(\sigma)\end{array}$} \\
\hline & & SA & $\mathrm{A}$ & UD & DA & SDA & & \\
\hline \multirow{2}{*}{$\begin{array}{l}\text { Educational } \\
\text { Development }\end{array}$} & $\begin{array}{l}\text { Focused on Better Computer } \\
\text { Education \& English Language }\end{array}$ & 47 & 34 & 13 & 6 & 0 & 4.2 & 0.9 \\
\hline & $\begin{array}{l}\text { Better Educational Programs for } \\
\text { Graduation \& Post-graduation }\end{array}$ & 31 & 61 & 6 & 2 & 0 & 4.2 & 0.6 \\
\hline \multirow{6}{*}{$\begin{array}{c}\text { Student } \\
\text { Development }\end{array}$} & $\begin{array}{l}\text { Highly Competent Students } \\
\text { for the J ob Market }\end{array}$ & 31 & 45 & 20 & 4 & 0 & 4 & 0.8 \\
\hline & Make Students a Good Citizen & 31 & 54 & 12 & 2 & 1 & 4.1 & 0.8 \\
\hline & Grooming of the Students & 26 & 59 & 10 & 3 & 2 & 4 & 0.8 \\
\hline & $\begin{array}{l}\text { Seminars \& Co-curricular } \\
\text { Activities for Personality } \\
\text { Development of Students }\end{array}$ & 45 & 36 & 12 & 4 & 3 & 4.2 & 1 \\
\hline & $\begin{array}{l}\text { Development of Scientific \& } \\
\text { Rational Thinking }\end{array}$ & 41 & 35 & 18 & 3 & 3 & 4.1 & 1 \\
\hline & $\begin{array}{l}\text { Efficient Guidance \& } \\
\text { Counseling for the Students }\end{array}$ & 36 & 52 & 2 & 8 & 2 & 4.1 & 0.9 \\
\hline \multirow{2}{*}{$\begin{array}{l}\text { Educational } \\
\text { Interest }\end{array}$} & $\begin{array}{l}\text { Variety of Scholarships \&Fee } \\
\text { concessions }\end{array}$ & 65 & 27 & 5 & 3 & 0 & 4.5 & 0.7 \\
\hline & $\begin{array}{l}\text { Achievement Appreciations of } \\
\text { the Students }\end{array}$ & 66 & 24 & 8 & 2 & 0 & 4.5 & 0.7 \\
\hline
\end{tabular}


Table 1 showed that the statement "Focused on Better Computer Education \& English Language" showed $47 \%$ agreement by the teachers with mean 4.2 and S.D $0.9 .61 \%$ teachers were agreed for providing better educational programs for Graduation and post-graduation by Private colleges having mean 4.2 with a small standard deviation of $0.6 .45 \%$ Teachers agreed that Private colleges prepare highly competent students for the job market by developing their academic and personal competencies, so its score laid at central tendency of 4.0 and S.D of 0.8 . $54 \%$ teachers agreed that Private colleges make students Good Citizen by applying personal and ethical values in Colleges, this statement showed a mean of 4.0 with standard deviation 0.8 . 59\% teachers agreed the role of Private colleges in the grooming of the Students mean 4.0 and S.D 0.8.

For the grooming of students different type of presentations, speeches, oral and written competitions are held in the College which are helpful in the grooming of students. Statement as "Seminars \& Co-curricular Activities for Personality Development of Students" 45\% agreed with mean score of 4.2 and S.D as 1.0. Moreover, $41 \%$ teachers agreed the statement that Development of Scientific \& Rational Thinking with mean value of 4.1 with a standard deviation of 1.0. The efficient Guidance \& Counseling for the Students statement was $52 \%$ agreed with a mean value and standard deviation as 4.1 and 0.9 respectively. Variety of Scholarships \& Fee concessions by the Private Colleges was very well appreciated by the teachers therefore this statement gained $65 \%$ agreement with a mean value of 4.5 and S.D 0.7. The vital role of Private Colleges in holding achievement appreciations of the Students was $66 \%$ agreed by the teachers which are obvious from remarkable mean value of 4.5 and a standard deviation of 0.7 .

To sum up the overall responses of above statements, teachers agreed with the enhanced positive role of Private Colleges in maintaining a good management, educational programs, molding and maintaining good students behavior and parent-teacher relationship. Teachers were satisfied with the efforts of Private Colleges for the Educational Development.

Table 2: Teacher's opinions about (Institutional Management, Physical Facilities and Staff development)

\begin{tabular}{|c|c|c|c|c|c|c|c|c|}
\hline \multirow{2}{*}{ Category } & \multirow{2}{*}{ Statement } & \multicolumn{5}{|c|}{ Percentage (\%) } & \multirow{2}{*}{$\begin{array}{l}\text { Mean } \\
(\mathrm{X})\end{array}$} & \multirow{2}{*}{$\begin{array}{l}\text { S.D } \\
(\sigma)\end{array}$} \\
\hline & & SA & $\mathrm{A}$ & UD & $\overline{\mathrm{DA}}$ & SDA & & \\
\hline \multirow{8}{*}{$\begin{array}{l}\text { Institutional } \\
\text { Management }\end{array}$} & $\begin{array}{l}\text { Effective Management for } \\
\text { Ouick and strict Actions }\end{array}$ & 63 & 30 & 6 & 1 & 0 & 4.6 & 0.7 \\
\hline & $\begin{array}{l}\text { Regular } \quad \text { Parent-Teacher } \\
\text { Meetings }\end{array}$ & 31 & 61 & 6 & 2 & 0 & 4.2 & 0.6 \\
\hline & $\begin{array}{l}\text { Proper Monthly Tests } \& \\
\text { Reports to Parents }\end{array}$ & 52 & 36 & 6 & 4 & 2 & 4.3 & 0.9 \\
\hline & $\begin{array}{l}\text { Free Working Atmospheres for } \\
\text { the Staff }\end{array}$ & 28 & 41 & 20 & 8 & 3 & 3.8 & 1 \\
\hline & $\begin{array}{l}\text { Students Strictly Obey the } \\
\text { Rules }\end{array}$ & 38 & 40 & 19 & 3 & 0 & 4.1 & 0.8 \\
\hline & $\begin{array}{l}\text { Discipline resulted no Bunking } \\
\text { of Lectures }\end{array}$ & 46 & 38 & 12 & 4 & 0 & 4.3 & 0.8 \\
\hline & $\begin{array}{l}\text { Strong Punishments against } \\
\text { Strikes \& Negative Activities }\end{array}$ & 38 & 35 & 15 & 9 & 3 & 3.9 & 1.1 \\
\hline & $\begin{array}{l}\text { Efficient System of Board } \\
\text { Registration \& Exam } \\
\text { Preparation }\end{array}$ & 61 & 31 & 7 & 1 & 0 & 4.5 & 0.7 \\
\hline $\begin{array}{l}\text { Physical } \\
\text { Facilities }\end{array}$ & $\begin{array}{l}\text { High Quality Equipments in } \\
\text { Labs }\end{array}$ & 49 & 45 & 4 & 1 & 1 & 4.4 & 0.7 \\
\hline $\begin{array}{c}\text { Staff } \\
\text { Development }\end{array}$ & $\begin{array}{l}\text { Regular Staff Meetings \& } \\
\text { Refresher Courses }\end{array}$ & 49 & 37 & 13 & 1 & 0 & 4.3 & 0.8 \\
\hline
\end{tabular}


The above table 2 showed that $63 \%$ teachers agreed that Private Colleges maintain an effective management for taking quick and strict actions against any defaults or premises repair and maintenance. This agreement is proved with mean 4.6 with a standard deviation of 0.7. Holding Regular Parent-Teacher Meetings in Private Colleges was 50\% agreed by the teachers to maintain the performance of students with mean value 4.4 and S.D 0.7. Private Colleges have maintained this important activity to call the parents of students and regularly inform them about the performance of their children. These activities are very fruitful for enhancing the teachinglearning process and developing students' performance. The statement about Free Working Atmospheres for the Staff was 41\% agreed showing 3.8 mean score and a standard deviation of 1.0. This statement was disagree by $8 \%$ teachers because they said that sometimes due to political influence upon College's management they are helpless in correcting the behavior of faulty students and also due to the prevailing traditional teaching methods they are not able to carry on teaching-learning process according to their own method.

Students strictly obey the Rules statement gained $40 \%$ agreement by the teachers with mean score of 4.1 and S.D as 0.8. This statement refers to the prevailing discipline practices in Private Colleges. Teachers respond that if the rules are followed strictly from top management than students also strictly obey the rules or vice versa. Moreover, $46 \%$ teachers agreed with the statement that "Discipline result no Bunking of Lectures" which is proved with the mean score and S.D as 4.3 and 0.8 respectively. Strong Punishments against Strikes \& Negative Activities gain 38\% agreement of teachers with a mean score of 3.9 and S.D of 1.1. The main cause of lower agreement for this statement was due to not giving punishments and penalties to faulty students in Private Colleges. Private Colleges held proper monthly tests and reports to Parents statement were 52\% agreed by the teachers which showed a mean score of 4.32 and S.D as 0.9.

Teachers favored this statement because they consider it an important practice for maintain ad enhancing the performance of students. The mean score of 4.5 proved that $61 \%$ agreement of teachers with the statement on the "Efficient System of Board Registration \& Exam Preparation" is true and having a S.D of 0.7. These days Private Colleges has maintained an excellent pattern to prepare their students for the final examinations and gain good marks and positions. Private Colleges maintain quality infrastructure, furniture and fixture, and all other physical facilities. Therefore, High Quality Equipments in Labs statement showed 45\% agreement of teachers having mean value of 4.4 with a S.D of 0.7. Other important statement such as "Regular Staff Meetings \& Refresher Courses" was $49 \%$ agreed by the teachers by showing the mean value of 4.3 and 0.8 S.D. Teachers stressed that the teachers training programs should contain new techniques and methods for teaching so that the level of information and techniques of teachers could be enhanced and the teaching-learning process could become a creative and interesting activity. The overall efforts of Private Colleges were greatly appreciated by the teachers and they wished for Pakistan to be an Educated, Developed and Prosperous Country in future.

Table 3: Student's opinions about (Educational Development, Students Development and Educational Interest)

\begin{tabular}{|c|c|c|c|c|c|c|c|c|}
\hline \multirow{2}{*}{ Category } & \multirow{2}{*}{ Statement } & \multicolumn{5}{|c|}{ Percentage (\%) } & \multirow{2}{*}{$\begin{array}{l}\text { Mean } \\
(\mathrm{X})\end{array}$} & \multirow{2}{*}{$\begin{array}{l}\text { S.D } \\
(\sigma)\end{array}$} \\
\hline & & SA & $\mathrm{A}$ & UD & DA & SDA & & \\
\hline \multirow{3}{*}{$\begin{array}{l}\text { Educational } \\
\text { Development }\end{array}$} & $\begin{array}{l}\text { Focused on Better Computer } \\
\text { Education \& Enqlish Lanquaqe }\end{array}$ & 52 & 33.5 & 11.5 & 3 & 0 & 4.4 & 0.8 \\
\hline & Better Educational Programs & & & & & & & \\
\hline & $\begin{array}{l}\text { for Graduation \& } \\
\text { graduation }\end{array}$ & 41 & 52 & 7 & 0 & 0 & 4.3 & 0.6 \\
\hline \multirow{4}{*}{$\begin{array}{c}\text { Student } \\
\text { Development }\end{array}$} & $\begin{array}{l}\text { Highly Competent Students } \\
\text { for the J ob Market }\end{array}$ & 30.5 & 51 & 13 & 5.5 & 0 & 4.1 & 0.8 \\
\hline & Make Students a Good Citizen & 34 & 52.5 & 11.5 & 2 & 0 & 4.2 & 0.7 \\
\hline & Grooming of the Students & 31.5 & 55.5 & 9.5 & 3.5 & 0 & 4.2 & 0.7 \\
\hline & Activities for Personality & 41.5 & 42 & 10 & 6 & 0.5 & 4.2 & 0.9 \\
\hline
\end{tabular}




\begin{tabular}{clrrrrrrr} 
& $\begin{array}{l}\text { Development of Scientific \& } \\
\begin{array}{l}\text { Rational Thinking } \\
\text { Efficient Guidance \& }\end{array}\end{array}$ & 36 & 40 & 19.5 & 4.5 & 0 & 4.1 & 0.9 \\
& $\begin{array}{c}\text { Counseling for the Students } \\
\text { Variety of Scholarships \& Fee }\end{array}$ & 29.5 & 49.5 & 16 & 5 & 0 & 4 & 0.8 \\
\hline $\begin{array}{c}\text { Educational } \\
\text { Interest }\end{array}$ & $\begin{array}{l}\text { concessions } \\
\text { Achievement Appreciations of } \\
\text { the Students }\end{array}$ & 65.5 & 26 & 4.5 & 0.5 & 0.5 & 4.6 & 0.6 \\
\hline
\end{tabular}

Table 3 manifest that the statement "Focused on Better Computer Education \& English Language" showed $52 \%$ agreement by students with a mean value of 4.4 and S.D of 0.8 . 52\% students agreed for another statement of providing the better educational programs for Graduation \& Post-graduation to the students by Private colleges and showed a mean 4.3 and a standard deviation of 0.6. Private Colleges prepare highly competent students for the J ob Market statement was $51 \%$ agreed by the students which result a mean of 4.1 and S.D of 0.8 . Again students favored the role of Private Colleges in developing the discipline and ethics in students thus $52.5 \%$ students agreed that Private colleges make students good citizen. Its mean 4.2 and standard deviation as 0.7 has proved the agreement of students. 55.5\% students agreed with the role of Private colleges in the grooming of the Students by the mean score of 4.2 and S.D 0.7 for the statement.

Seminars \& Co-curricular Activities for Personality Development of Students showed $42 \%$ agreement with mean value of 4.2 and S.D as 0.9 . $40 \%$ students agreed the statement as "Development of Scientific \& Rational Thinking” with mean of 4.1 having standard deviation of 0.9. The statement "Efficient Guidance \& Counseling for the Students" was 49.5\% agreed with a mean score and standard deviation as 4.0 and 0.8 respectively. The statement "Variety of Scholarships \& Fee concessions" gained 67.5\% agreement with mean value 4.6 and S.D 0.6. This statement was greatly favored by the students because it is easy for brilliant poor family students to get quality education at the Private Colleges. This scheme is very much attractive for the parents and also for the students to get good marks and gain the scholarships. Another important effort of Private Colleges in providing the achievement appreciations to the brilliant Students gain $65.5 \%$ agreed by the students which is proved from the remarkable mean score of 4.6 and a standard deviation of 0.7. The students agreed and satisfied with the management style, discipline and teaching-learning process in the Private Colleges.

Table 4: Student's opinions about (Institutional Management, Physical Facilities and Staff Development)

\begin{tabular}{|c|c|c|c|c|c|c|c|c|}
\hline \multirow{2}{*}{ Category } & \multirow{2}{*}{ Statement } & \multicolumn{5}{|c|}{ Percentage (\%) } & \multirow{2}{*}{$\begin{array}{l}\text { Mean } \\
(\mathrm{X})\end{array}$} & \multirow{2}{*}{$\begin{array}{l}\text { S.D } \\
(\sigma)\end{array}$} \\
\hline & & SA & $\mathrm{A}$ & UD & $\mathrm{DA}$ & SDA & & \\
\hline \multirow{8}{*}{$\begin{array}{l}\text { Institutional } \\
\text { Management }\end{array}$} & $\begin{array}{l}\text { Effective Management for } \\
\text { Quick and strict Actions }\end{array}$ & 51.5 & 44.5 & 3 & 1 & 0 & 4.5 & 0.6 \\
\hline & $\begin{array}{l}\text { Regular } \quad \text { Parent-Teacher } \\
\text { Meetinas }\end{array}$ & 54 & 35.5 & 8 & 1.5 & 1 & 4.4 & 0.8 \\
\hline & $\begin{array}{l}\text { Proper Monthly Tests \& } \\
\text { Reports to Parents }\end{array}$ & 55.5 & 33.5 & 6.5 & 4.5 & 0 & 4.4 & 0.8 \\
\hline & $\begin{array}{l}\text { Free Working Atmospheres for } \\
\text { the Staff }\end{array}$ & 54 & 44.5 & 16 & 7 & 2.5 & 3.9 & 1 \\
\hline & $\begin{array}{l}\text { Students Strictly Obey the } \\
\text { Rules }\end{array}$ & 44.5 & 37 & 11 & 6.5 & 1 & 4.2 & 0.9 \\
\hline & $\begin{array}{l}\text { Discipline resulted no Bunking } \\
\text { of Lectures }\end{array}$ & 49 & 35 & 8 & 5.5 & 2.5 & 4.2 & 1 \\
\hline & $\begin{array}{l}\text { Strong Punishments against } \\
\text { Strikes \& Negative Activities }\end{array}$ & 30 & 45.5 & 10 & 8.5 & 6 & 3.9 & 1.1 \\
\hline & $\begin{array}{l}\text { Efficient System of Board } \\
\text { Registration \& Exam Preparation }\end{array}$ & 55 & 35.5 & 7.5 & 2 & 0 & 4.4 & 0.7 \\
\hline
\end{tabular}




\begin{tabular}{clllllllll}
\hline $\begin{array}{c}\text { Physical } \\
\text { Facilities }\end{array}$ & $\begin{array}{l}\text { High Quality Equipments in } \\
\text { Labs }\end{array}$ & 57 & 33.5 & 9 & 0.5 & 0 & 4.5 & 0.7 \\
\hline $\begin{array}{c}\text { Staff } \\
\text { Development }\end{array}$ & $\begin{array}{l}\text { Regular Staff Meetings \& } \\
\text { Refresher Courses }\end{array}$ & 56 & 29.5 & 12 & 4.5 & 0 & 4.4 & 0.8 \\
\hline
\end{tabular}

The above table 4 showed that 51.5\% students agreed that the Private Colleges maintain an effective management for taking quick and strict actions mean score 4.5 and standard deviation 0.6. In Private Colleges the Holding of Regular Parent-Teacher Meetings was $54 \%$ agreed by the students with mean 4.4 and S.D 0.8. The statement "Free Working Atmospheres for the Staff" was $44.5 \%$ agreed by the students by showing 3.9 mean score and standard deviation of 1.0. Low percentage is the proof that the teaching in Private Colleges is not free from political influence because sometimes the teachers are not able to implement the punishments and penalties to the faulty students due to the management pressure or political influence upon them. Students Strictly Obey the Rules statement also showed low i.e. $44.5 \%$ agreement of the students with mean score of 4.2 and S.D of 0.9. 49\% students agreed with statement "Discipline result no Bunking of Lectures" with the mean score of 4.2 and S.D 1.0.

Statement such as Strong Punishments against Strikes \& Negative Activities" gained 45.5\% agreement of the students with a mean score of 3.9 and S.D of 1.1. The preceding three statements gain low agreement because students think that sometimes due to indulgent and relaxed environment of the colleges' students did not obey the rules of Private Colleges properly. Private Colleges held proper monthly tests and send reports to Parents for maintaining the better performance of the students which is obvious from 55.5\% agreement of students with a mean score of 4.4 and S.D 0.8. The mean score of 4.4 showed the 55\% agreement of students for the statement "Efficient System of Board Registration \& Exam Preparation" is true and having a S.D of 0.7. "High Quality Equipments in Labs" statement gains 57\% agreement of students with mean score of 4.5 and a S.D of 0.7. This significant percentage showed the satisfaction of students for the provision of physical facilities in the Private Colleges. Another statement as "Regular Staff Meetings \& Refresher Courses" gained 56\% agreement of the students with mean value of 4.4 and 0.8 S.D.

Table 5: Chi Square Statistics results of Statements' Association

\begin{tabular}{|c|c|c|}
\hline $\begin{array}{l}\text { Sr. } \\
\text { No }\end{array}$ & Statements & Chi Square \\
\hline 1 & $\begin{array}{l}\text { Effective management and } \\
\text { high quality education } \\
\text { factors are related }\end{array}$ & 1.032 \\
\hline 2 & $\begin{array}{l}\text { Better educational } \\
\text { programs and highly } \\
\text { competent students factors } \\
\text { are related }\end{array}$ & 1.079 \\
\hline 3 & $\begin{array}{l}\text { Make students good } \\
\text { citizens and strong } \\
\text { punishments factors are } \\
\text { related }\end{array}$ & 66.88 \\
\hline 4 & $\begin{array}{l}\text { Grooming and } \\
\text { development of scientific \& } \\
\text { rational thinking factors } \\
\text { are related }\end{array}$ & 1.721 \\
\hline 5 & $\begin{array}{l}\text { Variety of scholarships and } \\
\text { achievement appreciations } \\
\text { are related }\end{array}$ & 4.978 \\
\hline 6 & $\begin{array}{l}\text { Regular Parent-Teacher } \\
\text { Meetings and Proper } \\
\text { Monthly Tests factors are } \\
\text { related }\end{array}$ & 1.131 \\
\hline
\end{tabular}


Free working atmosphere

and regular staff meetings

1.305

factors are related

Students strictly obey the

rule and discipline factors

are related

Focused on better

9

education and efficient

system of registration

factors are related

Seminars \& co-curricular

10

activities and efficient

guidance factors are

related

In table 5, the calculated value of chi-square 1.03 lies in the critical region so we reject Ho and conclude that effective management and high quality education factors are co-related. The calculated value of chi-square 1.08 lies in the critical region of chi-square distribution so we reject Ho and conclude that better educational programs and highly competent students for the job market factors are related. The calculated value of chi-square 66.88 lies in the critical region of chisquare distribution so we reject Ho and conclude that factors to make students good citizens and strong punishments against strikes \& negative activities are related. The calculated value of chisquare 1.72 lies in the critical region so we reject Ho and conclude that above mentioned factors are related. The calculated value of chi-square 4.98 lies in the critical region so we reject Ho and conclude that above mentioned factors are related. The calculated value of chi-square 1.13 lies in the critical region so we reject Ho and conclude that regular parent-teacher meetings and proper monthly tests are co-related. The calculated value of chi-square 1.30 lies within the critical region so we reject Ho and conclude that above mentioned factors are co-related. The calculated value of chi-square 3.87 lies in the critical region so we reject Ho and conclude that above mentioned factors are related. The calculated value of chi-square 1.46 lies in the critical region so we reject Ho and conclude that focused on better education and efficient system of registration factors are co-related. The calculated value of chi-square 1.70 lies in the critical region so we reject Ho and conclude that Seminars \& co-curricular activities and effective for the students.

\section{Discussion and Conclusions}

This study has empirically shown that private colleges are significantly contributing for the development of effective education system in Rahim Yar Khan. A sizeable number of teachers and students agreed that Private Colleges have an effective management for taking quick and strict actions. They are preparing competent students for the job market. Majority of teachers and students agreed that Private Colleges emphasized to make the students a good citizen of the country. They are playing a vital role in the grooming of the students and they maintain high quality equipments in Labs.

Large number of teachers and students also look agree that Private Colleges developed the scientific and rational thinking of the students. They provide variety of scholarships and fee concessions to the deserving students for developing their interest in education and the achievement appreciations thus increase the interest of the students toward their studies. Lot of teachers and students agreed that Private Colleges held regular parent- teachers meetings for the better performance of the students. They provide free working atmosphere for the staff without any fear of political influence and in private colleges students strictly obey rules and regulations of colleges. A large majority also agreed that due to strict discipline in college students are unable to bunk their lectures. They also exercise strong punishments against strikes and negative activities. Teachers and students also agreed that in colleges proper monthly tests are held and send student's progress reports to their parents. Private Colleges' regular staff meetings and refresher courses have enhanced their competencies and they also maintain efficient system of Board registration and exam preparation. 
Majority of the teachers favored that Private Colleges have provide a scenario of better educational programs for Graduation as well as for Post-graduation. It is the platform where intelligent and knowledgeable graduates as well as post graduates are prepared. Everyone has his own view but some of the students were disagree that Private Colleges prepare highly competent students for the job market but some teachers were agreed to this role of Private Colleges. As the students of Private Colleges are confident and knowledgeable enough to compete in the job market therefore it is also a vital role of Private Colleges in grooming of its valuable students.

Most respondents also agreed that Private Colleges have high quality equipments in Computer Lab and in Science Laboratory for the enhanced competency of the students. Majority of the teachers and students favored that Private Colleges have developed the interest of students toward their studies by providing variety of scholarships, fee concessions and achievement appreciations. Through this practice students are motivated toward their education and willing to produce good results and be appreciated. Some of the respondents strongly disagreed that due to strong punishments students cannot do strikes and negative activities in Private Colleges but some respondents also favored this effective role of Private Colleges. Majority of the teachers and students agreed that Private Colleges arranged seminars, co-curricular activities and guidance and counseling for the personality development of the students.

\section{Recommendations}

Keeping in view the revealed findings of research and conclusion drawn, following recommendations are constructed. Private Colleges should remain consistent in their performance. Parents and Teachers should regularly co-ordinate with one another in order to maintain and enhance the performance of their children. Private Colleges should make it possible that the teaching learning process should be free from political influence. Rules should be observed strictly from top level management to lower level management of the College, only than discipline can be maintained. Punishments should apply without any discrimination for all the faulty individuals. Private Colleges should justify that their high fees and dues are just because of their valuable services.

\section{References:}

1. Dronkers, J . \& Avram, S. (2010). Social Class Dimensions in the Selection of a Private School: A Cross-National Analysis Using PISA. Educational Research and Evaluation, pp. 4-5.

2. Gay, L. R., \& Airasian, P. W. (2002). Educational research: Competencies for analysis and application. Lahore: National Book Foundation.

3. Government of Pakistan. (1998). National Education Policy (1998-2010). Islamabad: Ministry of Education.

4. Haider, S. Z., \& Hussain, A. (2014). Relationship between Teacher Factors and Student Achievement: A Co relational Study of Secondary Schools. US-China Education Review A, 4(7), 465-480.

5. Niazi, H. K., \& Mace, J. (2006). The Contribution of the Private Sector to Higher Education in Pakistan with Particular Reference to Efficiency and Equity. Bulletin of Education \& Research, 28(2), 17-42.

6. Rose, P. (2009). Editorial introduction: Non-state provision of education: Evidence from Africa and Asia. Compare, 39(2), 127- 134.

7. Tooley, J., \&Dixon, P. (2005). Private education is good for the poor: A study of private schools serving the poor in low-income countries. Washington, DC: Cato Institute. 